(C) М.М. Толстушко, к.т.н., Н.О. Толстушко, к.т.н., С.М. Юхимчук Луцький національний технічний університет

\title{
АНАЛІЗ РОБОТИ ВИВІДНОГО ПРИСТРОЮ ЛЬОНОЗБИРАЛЬНОЇ МАШИНИ
}

У статті наведено результати аналізу роботи вивідного пристрою льонозбиральної машини. Обтрунтовано окремі параметри вивідного пристрою льонозбиральної машини.

ЛЬОНОЗБИРАЛЬНА МАШИНА, ВИВІДНИЙ ПРИСТРІЙ, ВИВІДНИЙ ТРАНСПОРТЕР, ПАСИВНА ПОВЕРХНЯ, АКТИВНА ПОВЕРХНЯ, РОЗСТИЛАННЯ, СТЕБЛОВА СТРІЧКА ЛЬОНУ

Постановка проблеми. Вивідні пристрої льонозбиральних машин виконують процес розстилання стеблової стрічки льону на поверхні льоновища. Причому стеблові стрічки характеризуються такими показниками як відносна розтягнутість та перекіс стебел у стрічці, товщина стрічки. Актуальним $є$ підвищення якості розстилання стеблової стрічки льону на підставі удосконалення 
конструкції та обгрунтування параметрів вивідних пристроїв льонозбиральних машин [1-4].

Аналіз останніх досліджень і публікацій свідчить про те, що $\epsilon$ багато теоретичних, експериментальних i теоретикоекспериментальних досліджень присвячених саме вивідним пристроям льонозбиральних машин. Розроблення нових конструкцій вивідних пристроїв льонозбиральних машин продовжується у багатьох країнах світу. Необхідно відмітити роботи в цьому напрямку під керівництвом професора Г.А. Хайліса $[1,3,4]$.

У льонозбиральних машинах застосовуються вивідні пристрої з активними, пасивними та комбінованими робочими органами. За функціональним призначенням вивідні пристрої льонозбиральних машин поділяють на такі, які можуть виконувати, крім розстилання стеблової стрічки, наступні операції: підрівнювання, перевертання, плющення, повертання стеблової стрічки [1-4]. Поєднати декілька операцій зі стебловою стрічкою у вивідному пристрої льонозбиральної машини $\epsilon$ актуальним завданням [1-4].

Мета дослідження - проаналізувати роботу вивідного пристрою льонозбиральної машини.

Результати дослідження. Розміщений на льонозбиральній машині вивідний пристрій містить вивідний транспортер, пасивну і активну поверхні $[3,4]$. Під час роботи льонозбиральної машини стеблова стрічка подається із вивідного транспортера на похилу пасивну поверхню, де рухаючись стеблова стрічка поступово повертається i на виході 3 нього падає на активну поверхню вивідного пристрою. Активна поверхня нахилена у бік своєї планки i до напрямку руху машини, здійснює коливальний рух. Стебла рухаються відносно похилої активної поверхні i коренями взаємодіють з ії планкою, внаслідок чого стрічка підрівнюється. Далі стеблова стрічка 3 активної поверхні вивідного пристрою падає на льоновище.

Функціями вивідного транспортера є: приймання стеблової стрічки від робочих органів льонозбиральної машини; транспортування стеблової стрічки; подавання стеблової стрічки на пасивну поверхню вивідного пристрою.

Функціями пасивної поверхні $є$ : приймання стеблової стрічки від вивідного транспортера; повертання стеблової стрічки на кут біля дев'яносто градусів; спускання стеблової стрічки на активну поверхню вивідного пристрою. Функціями активної поверхні $\epsilon$ : приймання стеблової стрічки від пасивної поверхні; 
підрівнювання стеблової стрічки; спускання стеблової стрічки на льоновище.

До основних параметрів вивідного пристрою льонозбиральної машини належать: $L_{1}$ - довжина пасивної поверхні в зоні подавання стеблової стрічки від вивідного транспортера; $L_{2}$ - довжина пасивної поверхні в зоні спускання стрічки на активну поверхню; $R$ - радіус пасивної поверхні.

На рис. 1 зображена схема у просторовій системі координат $O_{1} x_{1} y_{1} z_{1}$ для обгрунтування параметрів вивідного пристрою льонозбиральної машини. Відстані $O E$ і $D E$ відповідно дорівнюють $L_{1}$ i $L_{2}$. Швидкість пасів вивідного транспортера у льонозбиральній машині дорівнює $\mathrm{v}_{T P}$. Льонозбиральна машина рухається в напрямі осі $O_{1} x_{1}$ зі швидкістю $\mathrm{v}_{M}$.

Рухаючись на похилій пасивній поверхні $O D E, \quad 3$ положення $C_{0} K_{0}$ в положення $C K$ (рис. 1), стебла повертаються на кут біля дев'яносто градусів. Криві $C_{0} C$ та $K_{0} K$ умовно відображають траєкторії руху характерних точок стебел льону (відповідно центра мас та кінця кореня стебел). Оскільки під час повертання стебел їх корені описують траєкторії $K_{0} K$, то довжина $L_{1}$ рівна сумі $O K_{0}+K_{0} E$, тут $O K_{0}$ - частина довжини $L_{1}$, яка забезпечує приймання стрічки, а відстань $K_{0} E=a$ потрібна для повертання стрічки.

Приймання стеблової стрічки забезпечується, якщо $O K_{0} \approx l_{\text {cep }}$, де $l_{\text {cep }}$ - середня довжина стебла льону. Враховуючи відносну розтягнутість стебел у стрічці та умови падіння стрічки на пасивну поверхню, необхідно, щоб $O K_{0} \approx k_{1} \cdot l_{\text {cep }}$, де $k_{1}=1,1 \ldots 1,2-$ коефіцієнт для уточнення поздовжніх габаритів пасивної поверхні вивідного пристрою. Тому, для обгрунтування довжини пасивної поверхні в зоні подавання стеблової стрічки одержимо:

$$
L_{1} \approx k_{1} \cdot l_{\text {cep }}+a \text {. }
$$

3 аналогічних міркувань визначається довжина $L_{2}$, яка дорівнює сумі $D K+K E$, де $D K \approx l_{\text {cep }}$, а $K E=b-$ відстань, яка необхідна для повертання стрічки. Якщо врахувати умови падіння стрічки та можливе відносне зміщення стебел у стрічці під час повертання, то $D K \approx k_{2} \cdot l_{\text {cep }}$, де $k_{2}=1,12 \ldots 1,20$ - коефіцієнт для уточнення поперечних габаритів активної поверхні вивідного 
пристрою. Отже, для обгрунтування довжини пасивної поверхні в зоні спускання стеблової стрічки на активну поверхню одержимо:

$$
L_{2} \approx k_{2} \cdot l_{\text {cep }}+b \text {. }
$$

Iз практики експлуатації експериментальної льонозбиральної машини, яка обладнана розробленим вивідним пристроєм, та 3 інших міркувань приймаємо, що $a \geq b$ i $a=0,05 \ldots 0,10 \mathrm{M}$.

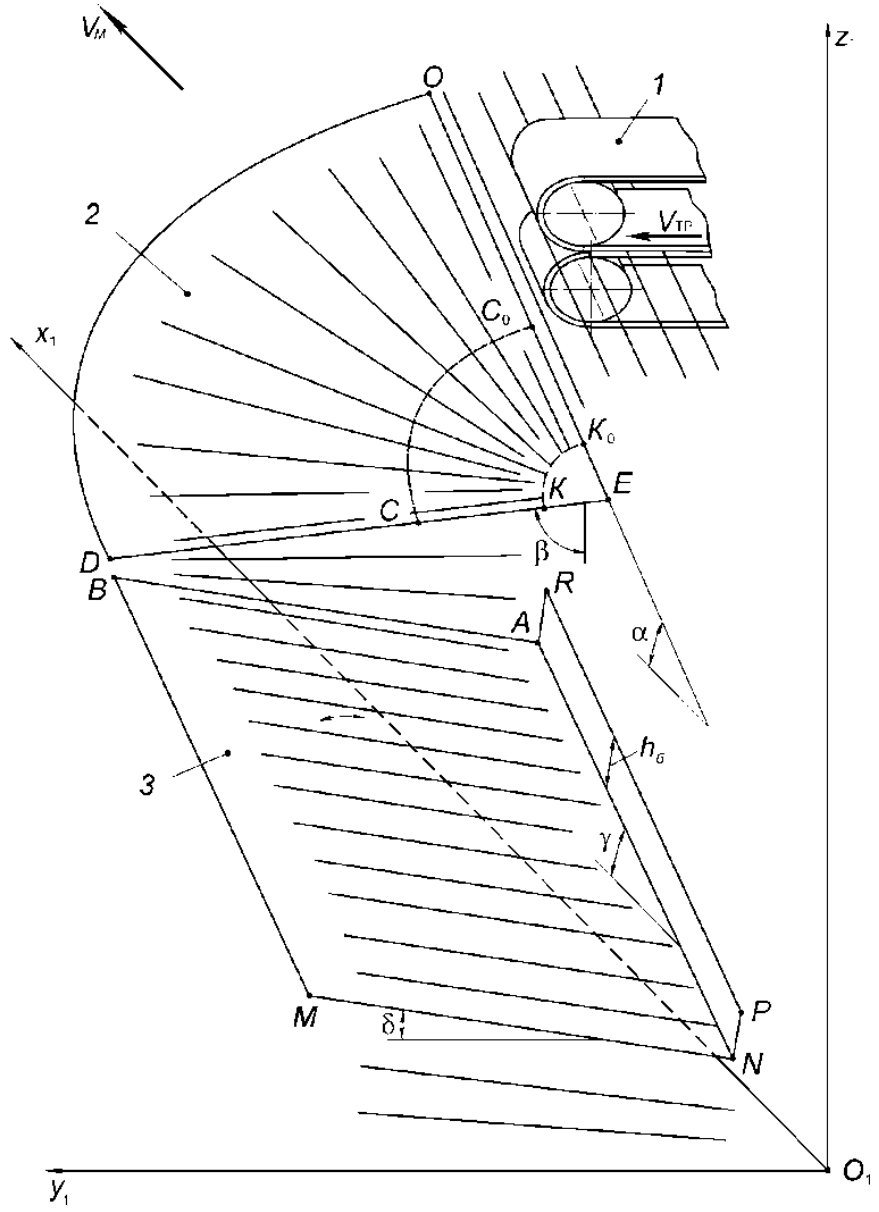

Рис. 1 - Схема до аналізу роботи вивідного пристрою льонозбиральної машини : 1 - вивідний транспортер; 2 - пасивна поверхня; 3 - активна поверхня. 
Висновки. За середньої довжини стебла льону
$l_{\text {cep }}=\left(l_{\min }+l_{\max }\right) / 2 \approx(0,70+1,30) / 2=1 \mathrm{M}$, де $l_{\min } \mathrm{i} \quad l_{\max }-$ відповідно мінімальна і максимальна довжина стебла [1-4], та при менших значення коефіцієнтів $k_{1}$ i $k_{2}$, визначимо $L_{1} \mathrm{i} L_{2}$ за формулами (1) і (2): $L_{1} \approx 1,1 \cdot 1+0,1=1,2 \mathrm{м} ; L_{2} \approx 1,12 \cdot 1+0,08=1,2$. Приймали: $a=0,1$ м; $b=0,08$ м. Отже, отримаємо: $L_{1}=L_{2}=1,2$ м.

Кінці коренів стебел стрічки під час руху описують криву $K_{0} K$ на пасивній поверхні вивідного пристрою та приймаючи умову, що $b \leq a$, радіус пасивної поверхні $R$ дорівнює $L_{1}$.

\section{Література}

1. Хайлис Г.А. Теория льноуборочных машин / Хайлис Г.А. М.: Росинформагротех, 2011. - 322 с.

2. Depoortere [Electronic resource]. - Mode of access: http://www.depoortere.be/. - Title from the screen.

3. Толстушко М.M. Обгрунтування параметрів i режиму роботи підрівнювача-розстилача стрічки стебел льону: дис. ... канд. техн. наук: 05.05.11 / Толстушко Микола Миколайович. - Луцьк, 2004. $-229 \mathrm{c}$.

4. Толстушко М.М. Розстилальні пристрої льонозбиральних машин / Толстушко М.М., Хайліс Г.А., Толстушко Н.О. - Луцьк: Ред.-вид. відділ ЛНТУ, 2014. - 160 с. 